\title{
DEEP DIVISIONS
}

\section{Archaeologists are unearthing remarkable finds in Jerusalem. But the digs have sparked an argument over who should run the site and present the results to the public. Haim Watzman reports.}

$\mathrm{n}$ the ancient heart of Jerusalem, the onekilometre-square walled area known as the Old City contains some of the most sacred sites for three religions, and as such it is no stranger to religious and political conflict. Yet some of the latest disputes are centred just outside the massive walls, in a Palestinian village known as Silwan that is now a neighbourhood within greater Jerusalem.

Here, archaeologists are battling over the interpretation of major ongoing excavations. The site, known to Israelis as the City of David, lies under part of Silwan and is operated by a Jewish settler organization. Some Israeli archaeologists are openly critical of this organization's aims, while many Palestinians claim that the digs are damaging their property. At the heart of the debate is the question of who should be allowed to control the site, oversee excavations, and present the findings to the public.

The part of Silwan that lies on top of the site contains some four dozen homes of Palestinian Arabs, and 20 homes of Israeli settlers. The houses stand on the ruins of centuries of Muslim and Byzantine habitation, which in turn cover the Jerusalem that was sacked and burned by the Babylonians in 586 BC, and before that besieged by the Assyrians in 701 BC. Farther down lies evidence that might help confirm - or refute - the Bible's account of a prosperous united Israelite kingdom in the tenth century $\mathrm{BC}$, ruled by the kings David and Solomon. And deeper still are the remains of an even more ancient city that prospered around 1800-1700 BC, during the Middle Bronze Age.

So it's hardly surprising that archaeologists have been excavating here for the past 140 years. Digs are now under way at several sites in Silwan - both between and beneath the homes of the village's inhabitants. Each month, busloads of Israeli schoolchildren and Israeli and foreign tourists flock to see the unearthed finds.

But to some, the way in which these finds are presented and explained to the visitors is a major cause for concern. The visitors' centre

Excavations near this ancient tunnel have revealed fresh details about how the Gihon spring was used. at the site is run by a non-profit foundation called Ir David (which means 'City of David' in Hebrew). The group was established in 1986 to promote excavation and tourist development of the site, and is popularly known by its Hebrew acronym, Elad. The foundation often helps to organize funds and support for archaeological excavations at the site.

But Elad also has another goal: promoting Jewish settlement in the village of Silwan. To that end, it has reclaimed formerly Jewish houses, evicting the Palestinian residents and replacing them with Jews, and has purchased Palestinian houses - sometimes using means that its Palestinian and Israeli critics charge are legally questionable. Renovation of these homes and development work for residential and tourist purposes have necessitated salvage excavations that have inconvenienced the Palestinian residents and sometimes caused damage to their property.

Elad's members and supporters are nearly all nationalist Orthodox Jews who believe that Jewish settlement in the territories captured by Israel in the Six-Day War of 1967 is God's will and a precondition for the arrival of the Messiah.

Although archaeologists digging at the site say that Elad has not pressed political interpretations on their work, some of them have raised concerns that the organization's religious and political goals are incompatible with the role of running a national park containing an important archaeological site. Indeed, they charge that Elad is using its position to promote a distorted version of history - merging myth and legend with archaeological fact.

This apparent conflict of interest has prompted a group of archaeologists to initiate legal moves to get the Israeli government to take control of the site from Elad. "They are taking over public land," says Rafi Greenberg, an archaeologist at Tel Aviv University who is one of the organizers of the initiative.

But Ronny Reich, an archaeologist at the University of Haifa who has excavated at the City of David, notes that Elad does not try to dictate who can work there. "I don't think anyone can tell a group of people that wants to participate in the excavations that they can't," he says. 


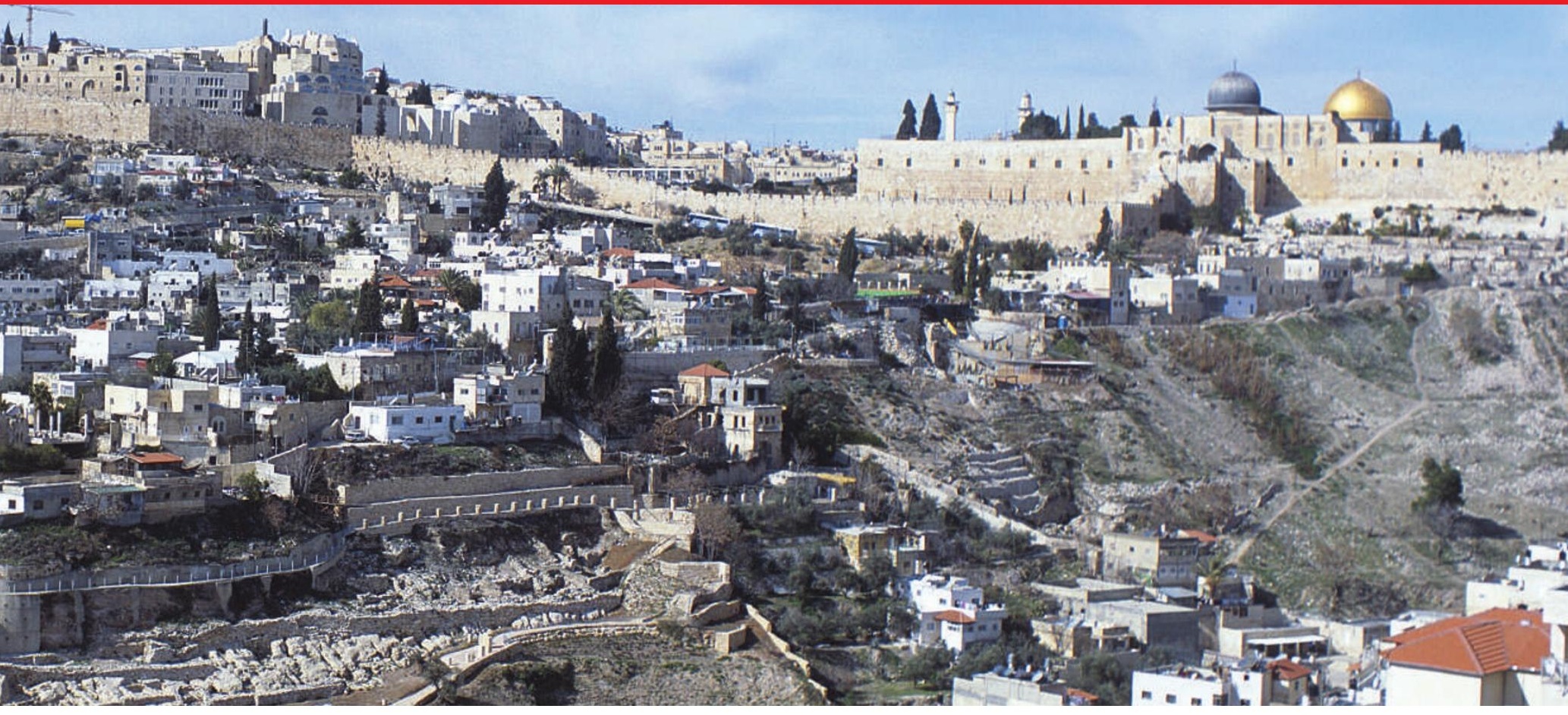

Just below Jerusalem's city walls stretches a hill that is home to the archaeological remains known as the City of David.

Elad's spokesman refused Nature's request to interview a representative of the organization and asked that questions be submitted in writing. When they were, the spokesman failed to provide answers, despite repeated promises to do so.

\section{Fact or fiction?}

One way to experience the Elad view of the City of David is to tour the site with an Eladtrained guide. It is possible to visit the excavations on your own or with a guide you've brought yourself. But the default option for tourists and school groups is to hear the narrative that asserts the Jewish claim and historical connection to the site, say Greenberg and his colleagues.

There is some truth to these claims, as a Nature visit to the site suggests. The tour guide provided by Elad was well-spoken and knowledgeable, but mixed myth and fact in her presentation. For example, she asserted that the reason David chose the site for his capital is that it lies just below the Temple Mount, which is identical to Mount Moriah, the site where, according to the Bible, Abraham took his son Isaac to offer him as a sacrifice to God. Although the identification of the Temple Mount with Mount Moriah is well-established in Jewish tradition, there is no archaeological evidence for Abraham's presence on the site - or indeed for the existence of Abraham and Isaac.

In fact, a handful of archaeologists go so far as to say that David and Solomon may also be largely mythical characters. This view is rejected by most experts on the period - they tend to agree that it is likely the two ancient rulers did reign in Jerusalem. But many scholars argue that the evidence discovered so far - both at the City of David and at other sites in the region - indicates that the biblical description of the extent and wealth of their kingdoms is exaggerated.

Furthermore, the Elad guide made no mention of Byzantine and Muslim settlement, giving the impression that the site is solely a Jewish one. But this may not be too surprising, given that she had only about an hour to explain the site and that her audience consisted of Israeli Jews, including a number of easily bored children and teenagers. Under those conditions, the presentation of any archaeological site would no doubt be geared more towards storytelling than to the detailed technical facts of what the archaeologists have found and how they interpret the evidence.

Few dispute that this complex site has yielded some major discoveries in recent years. Near the top of the hill in Silwan is an ongoing excavation led by Eilat Mazar of the Hebrew University and sponsored by Elad, the Shalem Center (a Jerusalem-based research institute), the Israel Antiquities Authority and the Society for the Study of the Land of Israel and Its Antiquities. In early 2005, Mazar's team uncovered a large stone structure,

and dated pottery found inside the structure to early in the Iron Age IIa

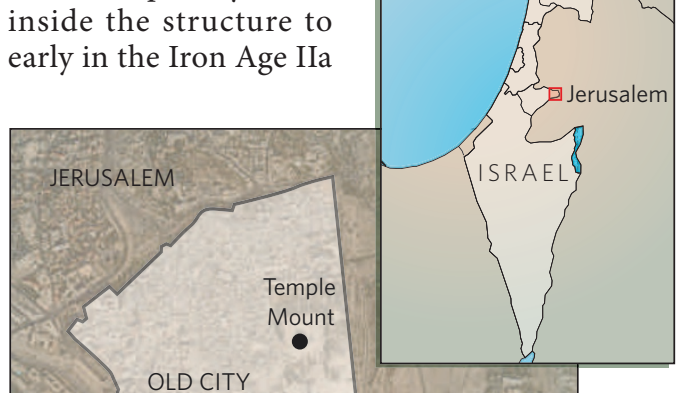

OLD CITY

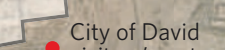

City of David

Gihon spring

Pool of Siloam period (around $1000 \mathrm{BC}$ ), which corresponds to the time of King David. So far, several large rooms have been uncovered, as well as walls two to three metres wide. In March, Mazar announced the discovery of another 20-metre section of the structure's outer wall, further evidence of its huge size. She believes that the massive nature of the structure indicates that it must have been an important public building.

And because it is located close to the Temple Mount and at a commanding position in the city, she believes that it is the palace that, according to the Bible, David built after conquering Jerusalem and making it his capital in the early tenth century $\mathrm{BC}^{1}$.

\section{Age concerns}

But some archaeologists dispute her dating and interpretation. Israel Finkelstein of Tel Aviv University, for example, is a leading proponent of the view that many archaeological remains throughout Israel dated to the early tenth century BC - the time of David and Solomon - are actually nearly a century younger. On the basis of his later dating of the artefacts in question, and of the lack of references to a large Israeli kingdom centred in Jerusalem in the records of near-Eastern cultures, he argues that the rulers of Jerusalem were not significant players on the international stage until much later. "Mazar has done fine and important work," he says, "but interpretation is another matter. The structure she found can't be dated unambiguously."

Finkelstein thinks that the large stone structure instead dates to the ninth century $\mathrm{BC}-$ the period in which Omri and his son Ahab organized the northern Israelite tribes into a powerful kingdom. He argues that the 
